\title{
HUBUNGAN PENGETAHUAN HIDUP BERSIH DAN SEHAT DENGAN PERILAKU CUCI TANGAN DI ERA PANDEMI COVID-19
}

\author{
THE RELATIONSHIP OF CLEAN AND HEALTHY LIFE KNOWLEDGE WITH \\ HAND WASHING BEHAVIOR IN THE ERA OF THE COVID-19 PANDEMIC
}

\author{
Desi Kurniawati ${ }^{1}$, Idayati ${ }^{2}$, Adi Kuswanto ${ }^{3}$ \\ ${ }^{1}$ Fakultas Kesehatan Universitas Muhammadiyah Pringsewu \\ Email Correspondence: desi_kurniawati@yahoo.com
}

\begin{abstract}
The Relationship Of Clean And Healthy Life Knowledge With Hand Washing Behavior In The Era Of The Covid-19 Pandemic. Hand washing is a strategy that is used to protect oneself from exposure to various disease-causing agents. Behavioral changes in school-age children are also needed, so that children are aware of the importance of good hand washing as a way to prevent exposure to COVID-19. The purpose of this study was to find a relationship between knowledge of clean and healthy living with hand washing behavior in the pandemic era at SDN 3 Sukaraja. The research method uses an analytical survey with a cross sectional approach. The population in this study were fourth and fifth grade students at SDN 3 Sukaraja, the sampling technique used a total sampling of 48 students, the statistical test used was the spearman rank technique. The results of the study found that there was a relationship between knowledge of clean and healthy living and hand washing behavior in the pandemic era at SDN 3 Sukaraja with a p-value of 0.01 $(<0.05)$. Students are expected to be able to apply handwashing properly to reduce the risk of being exposed to COVID-19 which can endanger themselves and others around them.
\end{abstract}

Keywords : PHBS, hand washing, covid-19, Knowledge

\begin{abstract}
Abstrak: Hubungan Pengetahuan Hidup Bersih Dan Sehat Dengan Perilaku Cuci Tangan Di Era Pandemi Covid-19. Perilaku cuci tangan merupakan strategi yang dilakukan demi menjaga diri dari paparan berbagai agen pencetus penyakit. Perubahan perilaku pada anak usia sekolah juga diperlukan, supaya anak sadar akan pentingnya cuci tangan yang baik sebagai cara pencegahan paparan covid-19. Tujuan penelitian ini adalah untuk mencari hubungan antara pengetahuan hidup bersih dan sehat dengan perilaku cuci tangan era pandemi di SDN 3 Sukaraja. Metode penelitian menggunakan survey analitik dengan pendekatan cross sectional. Populasi dalam penelitian ini adalah murid kelas IV dan V di SDN 3 Sukaraja, teknik pengambilan sampel menggunakan total sampling sebanyak 48 siswa, uji statistic yg digunakan yaitu teknik rank spearman. Hasil penelitian menemukan bahwa terdapat hubungan antara pengetahuan hidup bersih dan sehat dengan perilaku cuci tangan era pandemi di SDN 3 Sukaraja dengan $p$-value 0,01 (< $0,05)$. Siswa diharapkan bisa menerapkan cuci tangan dengan baik untuk mengurangi resiko terpapar covid-19 yang dapat membahayakan dirinya dan orang lain di sekitarnya.
\end{abstract}

Kata Kunci : PHBS, cucitangan, covid-19, Pengetahuan

\section{PENDAHULUAN}

Perilaku Hidup Bersih dan Sehat (PHBS) adalah sekumpulan perilaku yang dipraktikan atas dasar kesadaran sebagai hasil pembelajaran yang menjadikan seseorang atau keluarga yang dapat menolong diri sendiri dibidang kesehatan dan berperan aktif dalam mewujudkan kesehatan masyarakatnya. Anak usia sekolah dasar (SD) merupakan masa keemasan untuk menanamkan perilaku seperti Perilaku Hidup Bersih dan Sehat sehingga kedepannya akan membentuk perilaku mereka 
Vol 11 No 1 Januari 2022 | Page 170-175

untuk memiliki kemampuan dan kemandirian dalam mencegah penyakit, meningkatkan kesehatannya serta dapat berperan aktif dalam mewujudkan lingkungan yang sehat baik di sekolah, di keluarga maupun di masyarakat (rosyida 2019).

PHBS merupakan suatu upaya kesehatan yang dilakukan demi menjaga diri dari paparan berbagai agen pencetus penyakit. Salah satu PHBS yang dapat dilakukan adalah mencuci tangan menggunakan air bersih yang mengalir menggunakan sabun setelah menyentuh atau beberapa jam sekali maupun sebelum makan dan sesudah buang air besar dan setelah bepergian. Cuci tangan bertujuan untuk membunuh bakteri, virus maupun mikroorganisme lainnya. (shahputri \& sopia 2020)

Upaya yang dapat dilakukan keluarga dalam menerapkan PHBS adalah mencuci tangan dengan sabun dan air mengalir, menyediakan air bersih, konsumsi makanan bergizi, dan melakukan aktivitas fisik. Hal tersebut beberapa aktivitas yang berkaitan dengan upaya PHBS yang bisa melibatkan anak dalam keluarga (prabowo 2016). Mencuci tangan menjadi sangat penting saat ini, dimana kejadian pandemi covid-19 masih melanda dunia.Covid-19 dapat selain menular melaui airborn maupun droplet, namun juga dapat melalui sentuhn.Tangan yang terkontaminasi kemudian tanpa sadar menyentuh bagian tubuh seperti mata, hidung dan mulut dapat menjadi penyebab paparan covid19.Cuci tangan pada masa pandemi dianjurkan sesering mungkin dan dapat dilakukan dimanapun (Almarinda, 2020).

Saat ini Pandemi Virus Corona (Covid 19) telah melanda di berbaga Negara dibelahan dunia salah satunya yaitu Negara Indonesia. Data WHO menyebutkan kasus covid-19 telah mencapai 127.150.285 kejadian di seluruh dunia pada rentang waktu Januari 2010 sampai dengan Maret 2021. Sementara di Indoensia kejadian covid-19 tercatat sebanyak 1.501 .093 kasus pada rentang waktu bulan Maret 2020 - Maret 2021 dan diproyeksikan masih terus bertambah setiap harinya (WHO, 2021).

Penelitian yang dilakukan oleh Zulaikha,C dan Rochmayani, D, (2020) menemukan bahwa siswa usia sekolah di SDN Krapyak ada hubungan antara pengetahuan tentang PHBS dengan perilaku hidup sehat siswa PMR di SDN Krapyak dimana siswa dengan pengetahuan baik cenderung rutin melakukan cuci tangan di tempat yang sudah disediakan, dan siswa dengan pengetahuan kurang baik cenderuh acuh dengan kegiatan cuci tangan.

Hasil Prasurvey wawancara yang dilakukan di SDN 3 Sukarajasaat pandemi covid-19 menemukan bahwa sudah terdapat tempat mencuci tangan di setiap depan kelas namun satu kelompok dengan keseluruhan 15 siswa didapatkan hasil 11 siswa tidak faham bagaimana cara cuci tangan yang baik dan benar. Berdasarkan hasil prasurvey dan wawancara, peneliti tertarik untuk meneliti tentang hubungan pengetahuan perilaku hidup bersih dan sehat dengan mencuci tangan era pandemi di SDN 3 Sukaraja.

\section{METODE}

Rancangan penelitian menggunakan cross sectional, Populasi dalam penelitian ini adalah muridkelas 4 dan 5 di SDN 3 Sukaraja yang berjumlah 48 siswa, Pengambilan sampel menggunakan teknik total sampling dan uji statistik menggunakan rank spearman. 
Vol 11 No 1 Januari 2022 | Page 170-175

\section{HASIL}

Responden dalam penelitian ini adalah murid kelas 4 dan 5 di SDN 3 Sukaraja Tahun 2020 yang berjumlah 46 responden. Adapun hasil karakteristik berdasarkan usia, jenis kelamin dan dan kelas sebagai berikut.

Tabel 1. Distribusi frekuensi karakteristik responden berdasarkan kelas, jenis kelamin dan usia di SDN 3 SukarajaTahun 2021

\begin{tabular}{lcc}
\hline Karakteristik & Frekuensi (n) & Persentase (\%) \\
\hline Kelas & & \\
- Kelas IV & 23 & 47.9 \\
- Kelas V & 25 & 52.1 \\
\hline Jenis Kelamin & & \\
- Laki-Laki & 26 & 54.2 \\
- Perempuan & 22 & 45.8 \\
Usia & & \\
- 10 Tahun & 17 & 35.4 \\
- 11 Tahun & 28 & 58.3 \\
- 12 Tahun & 3 & 6.3 \\
Jumlah & 48 & 100 \\
\hline
\end{tabular}

Diketahui bahwa murid di SDN 3 Sukaraja yang duduk di kelas IV terdapat 23 siswa dan 25 siswa duduk di kelas V. Berdasarkan jumlah keseluruhan siswa laki-laki menjadi terbanyak. Kemudian didominasi siswa berusia 11 tahun dengan persentase 58,3Setiap tabel harus memiliki judul yang jelas tapi ringkas.

Tabel 2. Distribusifrekuensiberdasarkanpengetahuanperilakuhidupbersihdansehatsiswakelas IV-V di SDN 3 SukarajaTahun 2021

\begin{tabular}{lcc}
\hline Pengetahun PHBS & Frekuensi & Persentase (\%) \\
\hline Baik 76\%-100\% & 21 & 43.8 \\
\hline Cukup 56\%-75\% & 20 & 41.7 \\
Kurang< 55\% & 7 & 14.6 \\
Jumlah & 48 & $100 \%$ \\
\hline
\end{tabular}

Pengetahuan perilaku hidup bersih dan sehat responden berdasarkan tabel 4.2 didapatkan bahwa pengetahuan baik menjaditerbanyakyaitusejumlah 21 siswa, kemudian pengetahuan cukupsebanyak 20 siswa, dan hanya tujuh siswa dengan pengetahuan kurang. 
Vol 11 No 1 Januari 2022 | Page 170-175

Tabel 3. Distribusifrekuensiberdasarkanperilakumencucitangan di era pandemi Covid-19 padasiswakelas IV-V di SDN 3 SukarajaTahun 2021

\begin{tabular}{lcc}
\hline PerilakuCuciTangan & Frekuensi & Persentase (\%) \\
\hline Baik $>3$ & 30 & 62.5 \\
TidakBaik $\leq 3$ & 18 & 37.5 \\
\hline Jumlah & 48 & $100 \%$ \\
\hline
\end{tabular}

Perilaku cuci tangan berdasarkan tabel didapatkan hasil bahwa siswa dengan perilaku cuci tangan di era pandemi yang baik sebanyak 30 siswa dan tidak baik sebanyak 18 siswa. Sehingga mayoritas siswa baik dalam perilaku cuci tangan dengan persentase 62,5.

Tabel 4. Distribusi Frekuensi Hubungan Pengetahuan Hidup Bersih Dan Sehat Dengan Perilaku Cuci Tangan Era Pandemi di SDN 3 Sukaraja

\begin{tabular}{|c|c|c|c|c|c|c|c|}
\hline \multirow{3}{*}{$\begin{array}{c}\text { Pengetahuan } \\
\text { PHBS }\end{array}$} & \multicolumn{4}{|c|}{$\begin{array}{l}\text { Perilaku Cuci Tangan di } \\
\text { Era Pandemi }\end{array}$} & \multicolumn{2}{|c|}{ Total } & \multirow{3}{*}{ P Value } \\
\hline & \multicolumn{2}{|c|}{ Baik } & \multicolumn{2}{|c|}{ Tidak Baik } & \multirow{2}{*}{$\mathbf{N}$} & \multirow{2}{*}{$\%$} & \\
\hline & $\mathbf{N}$ & $\%$ & $\mathbf{N}$ & $\%$ & & & \\
\hline Baik & 16 & 33,3 & 5 & 10,4 & 21 & 43,8 & \multirow{4}{*}{0,05} \\
\hline Cukup & 14 & 29,2 & 6 & 12,5 & 20 & 41,7 & \\
\hline Kurang & 0 & 0,0 & 7 & 14,6 & 7 & 14,6 & \\
\hline Jumlah & 30 & 62,5 & 18 & 37,5 & 48 & 100 & \\
\hline
\end{tabular}

Berdasarkan tabel 4.6 responden pengetahuan tentang PHBS dengan perilaku cuci tangan di era pandemi di SDN 3 Sukaraja didapatkan hasil siswa dengan pengetahuan PHBS baik dengan perilaku cuci tangan baik sebanyak 16 (33,3\%), dengan perilaku cuci tangan tidak baik sebanyak $5(10,4 \%)$. Kemudian siswa dengan pengetahuan PHBS cukup dengan perilaku cuci tangan baik sebanyak 14 $(29,2)$, namun yang perilaku mencuci tangan tidak baik sebanyak $6(12,5)$. Lalu siswa dengan pengetahuan PHBS kurang tidak ada yang melakukan perilaku cuci tangan dengan baik dan terdapat 7 $(14,6)$ siswa dengan perilaku cuci tangan tidak baik. Berdasarkan uji Rank Spearman didapatkan hasil bahwa terjadi hubungan yang signifikan antara pengetahuan hidup bersih dan sehat dengan perilaku cuci tangan era pandemi di SDN 3 Sukaraja Tahun 2020 dengan $p$-value $(0,05)$ yang berarti < 5\% $(0,05)$ dan menunjukan bahwa Ho berhasil ditolak.

\section{PEMBAHASAN}

Pengetahuan akan berimplikasi pada penerapan dalam berperilaku, dimana pengetahuan mendorong individu melakukan hal yang sesuai dengan apa yang diketahui, sehingga jika dikaitkan dengan PHBS dan perilaku cuci tangan maka individu yang berpengetahuan tentang PHBS akan terdorong dalam melakukan cuci tangan yang baik (Haryani, Pujiastuti, \& Minardo, 2021).

Pengetahuan yang baik tentang pentingnya PHBS di masapandemi covid-19 mempengaruhi bagaimana anak dalam menerapkan perilaku cuci tangan yang mana terangkum dalam protocol 
Vol 11 No 1 Januari 2022 | Page 170-175

kesehatan yang menjadi kebijakan pemerintah dalam menghadapi pandemi covid-19. Pesertadidik dengan pengetahuan baik tentang PHBS cenderung taat dalam melakukan perilaku cuci tangan, dimana peserta didik sadar dengan dilakukanya cuci tangan akan membunuh mikroorganisme berhabaya yang menempel di tangan(Salsabila, Kartini, Anyelir, Arif, \& Firdaus, 2020).

Penelitian yang dilakukan Lestari (2019) menemukan bahwa anak yang memiliki pengetahuan kurang baik tentang PHBS memiliki perilaku cuc itangan yang tidak baik. Anak yang memiliki pengatahuan PHBS yang kurang baik lebih cenderung acuh terhadap perilaku menjaga kebersihan diri seperti mencuci tangan, anak akan kurang memiliki sikap, dorongan dan kemauan terkait perilaku mencuci tangan yang baik dan benar

Penelitian yang dilakukan Sihite,N., Podojoyo \& Yusuf. (2021). menemukan bahwa pendampingan dan edukasi meningkatkan pengetahuan yang berimplikasi kepada perilaku cuci tangan saat masa pandemi saat ini. Hal tersebut membuktikan bahwa tingkat pengetahuan beriringan dengan perilaku maupun sikap dalam mencuci tangan.

\section{SIMPULAN}

Berdasarkan hasil penelitian didapatkan karakteristik responden didominasi jenis kelamin lakilaki dan usia 11 tahun. Sebagian besar responden berpengetahuan baik yaitu sebesar 21 (43.8\%), sebagian besar responden melakukan perilaku cuci tangan dengan baik yaitu sebesar $30(62.5 \%)$ dan terdapat hubungan yang signifikan antara pengetahuan hidup bersih dan sehat dengan perilaku cuci tangan era pandemi di SDN 3 Sukarajadengan $p$ value $(0,01)$

\section{SARAN}

Penelitian ini disarankan berfokus pada pendidikan kesehatan ataupun penyuluhan, serta pelaksanaan PHBS terus dilakukan setiap hari sebagai upaya pemutusan mata rantai penularan covid19.

\section{DAFTAR PUSTAKA}

Almarinda. (2020). Pengetahuan Anak Usia Sekolah Tentang Hand Hygiene Terhadap Penyebaran Covid-19 di SDN 018 Harapan Tani Kabupaten Indragiri Hilir Taun 2020

Haryani, S., Pujiastuti, A. P., \& Minardo, J. (2021). Pengetahuan dan Perilaku Mencuci Tangan Pada Siswa SMK Sebagai Upaya Pencegahan Covid-19. Cendekia Utama, Vol. 10.

Prabowo, A. (2016). Hubungan Perilaku Hidup Bersih dan Sehat (PHBS) dengan Frekuensi Sakit Anggota Keluarga. PROFESI, Volume 13.

Rosyidah, A. N. (2019). Perilaku Cuci Tangan Terdahdap Kejadian Diare Pada Siswa di Sekolah Dasar Negeri Ciputat 02. Jurnal Ilmiah Keperawatan Orthopedi, Vol. 3.

Sahputri, J., \& Sofia, R. (2020). Penyuluhan Protokol Kesehatan Era Pandemi Coronavirus Desease (Covid-19) Di Sdn 14 Muara Dua Kota Lhoksemumawe. Lentera, Volume 4.

Salsabila, A. F., Kartini, A. P., Anyelir, D. F., Arif, M., \& Firdaus, M. (2020). Implementasi Program Mencuci Tangan Dalam Memutus Mata Rantai Penyebaran Covid-19. Universitas Negeri Semarang. 


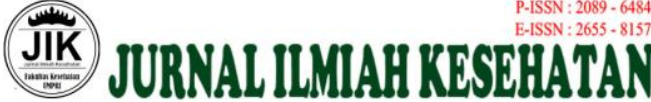

Vol 11 No 1 Januari 2022 | Page 170-175

Sihite,N., Podojoyo \& Yusuf. (2021). Edukasi Perilaku Cuci Tangan Pakai Sabun (CTPS) Bagi Lansia di Panti Sosial Tresna Wreda Teratai. Jurnal Inovasi dan Penerapan Ipteks Vol.9 No.2 Agustus 2021

Zulaikha, C \& Rochmayani, D.,S. (2020). Hubungan Pengetahuan tentang Perilaku Hidup Bersih dan Sehat (PHBS) dengan Perilaku Hidup Sehat Siswa PMR DI SDN KRAPYAK. Jurnal Ilmu Keperawatan dan Kebidanan.

WHO. (2021). WeeklyOperational Update on Covid-19: World Health Organitation. 